\title{
A MERITOCRACIA POSSÍVEL
}

por Felix Garcia Lopez Junior*

BELLOW, Adam. In praise of nepotism: a natural history. New York: Doubleday, 2003. 566p.

No momento em que a sociedade brasileira assiste as disputas em torno da legalidade e da legitimidade das nomeações de parentes para cargos de confiança no Poder Judiciário, que algumas Assembléias Legislativas aprovam projetos proibindo a contratação de parentes na administração pública (Rio de Janeiro e Paraná foram os primeiros), e que a discussão em torno do tema vai ganhando dimensões mais públicas que em qualquer outro período de nossa história, In praise of nepotism, livro do jornalista norte-americano Adam Bellow, é uma boa oportunidade de debater teoricamente a questão. Sobretudo porque, como o próprio Bellow ressalta, existem pouquíssimas pesquisas sobre o nepotismo: "Um dos aspectos mais notáveis do nepotismo é que ninguém escreveu um livro sobre o tema" (p. 21). Nosso país é um exemplo típico do descompasso entre a relevância sociológica da prática do nepotismo nas instituições e os poucos estudos dedicados ao tema.

O livro divide-se em duas partes. A primeira analisa os tipos de nepotismo praticados em diversas épocas históricas, em diferentes civilizações e sociedades; a segunda, a história do nepotismo nos Estados Unidos.

Cada capítulo da primeira parte é uma instigante discussão sobre o nepotismo em sociedades não-ocidentais, entre hebreus,

* Doutor em Sociologia pela Universiade Federal do Rio de Janeiro (UFRJ), professor visitante da Universidade Estadual do Rio de Janeiro (UERJ).

E-mail: felixglopez@gmail.com 
gregos, romanos antigos e na cristandade ocidental e, ainda, uma descrição das estratégias nepotistas dos Bórgia, dos Bonaparte e dos Rothschild.

A parte referente à história do nepotismo nos Estados Unidos é uma análise mais preocupada em avaliar as práticas de nepotismo das grandes e influentes famílias e das lideranças políticas norteamericanas.

Um dos principais argumentos do livro é que o nepotismo na política (e também nos negócios, esportes etc.) americana tem um sentido duplo. Primeiro, mostra que o nepotismo venceu parte das resistências do sistema meritocrático porque é constitutivo da natureza humana. Bellow aponta as evidências da sociobiologia para sustentar a persistência das diversas formas de nepotismo nas sociedades humanas, recorrendo por vezes à comparação com comportamentos de outros animais para mostrar os impulsos naturais que nos levam a favorecer nossos parentes. A propensão natural que fomenta o nepotismo é canalizada de acordo com os diferentes padrões culturais que, nas sociedades modernas dos últimos dois séculos, sob o manto da ideologia meritocrática, passaram a se contrapor de modo crescente a qualquer prática de nepotismo.

De fato, como Weber, Parsons e outros sociólogos já ressaltaram, a diferenciação social crescente das sociedades modernas apresenta uma clara tendência de separar e reduzir a importância dos vínculos de parentesco em todas as esferas sociais, como a política, a economia e a religião. Para Bellow, a sociedade americana experimenta, em parte, uma tendência em sentido contrário. Baseado em sociobiólogos como Steven Pinker, Mary Maxwell e Edward O. Wilson, o autor escreve que "nosso bias cultural contra o nepotismo pode estar mascarando nossa visão sobre seu verdadeiro caráter." A sociobiologia adverte que o nepotismo é natural (daí o subtítulo do livro) e que a prática existe porque está inscrita em nossos genes. ${ }^{1} \mathrm{O}$ livro avança o argumento e procura demonstrar que as sociedades humanas inovaram nas formas de nepotismo biológico porque há dois aspectos qualitativamente distintos do nepotismo 
das outras espécies: o nepotismo paterno (ao lado do universal nepotismo da mãe em relação ao filho) e o nepotismo estendido, surgido com os novos laços de nepotismo dos sistemas culturais de parentesco. Duas motivações fundem-se no nepotismo dos humanos: o "imperativo reprodutor", i.e., a necessidade do gene se perpetuar nas gerações futuras, e, os fins culturais, i.e., "a transmissão de propriedade, conhecimento e valores de uma geração à outra" (p. 78). Essa tendência a favorecer os parentes mais próximos, no entanto, pode assumir muitas formas, e, com isso, seu conceito de nepotismo via se alargando, quase perdendo utilidade heurística. Para Bellow, nepotismo é todo favorecimento derivado dos vínculos de parentesco. Favorecimento é um termo que se refere às decisões que não se baseiam exclusivamente em critérios meritocráticos. Porém, o autor não diferencia a esfera pública da esfera privada, de modo que a prática do nepotismo pode se estender a todas as instituições da sociedade, como os esportes, as artes, o jornalismo e as empresas privadas, das quais $95 \%$ ainda são controladas ou administradas por famílias nos EUA.

A análise relativa ao nepotismo na América é motivada pela curiosidade em saber se há paradoxo no revigoramento do nepotismo na sociedade norte-americana - e sua relativa aceitação social -, apesar dos princípios individualistas e meritocráticos/igualitários da forte tradição liberal daquele país. Mas o que pareceria, à primeira vista, um paradoxo, se desfaz, porque o novo nepotismo americano é de tipo "meritocrático" (Bellow), ou seja, aquele nepotismo que resulta do bom desempenho e mérito dos descendentes.

Ao longo da história política e administrativa americana, o nepotismo foi ganhando visibilidade devido ao conflito crescente entre as atribuições de direitos por mérito ou nascimento. $\mathrm{O}$ desenvolvimento da democracia moderna fez o pêndulo oscilar continuamente para o mérito, e as prerrogativas (ou privilégios) associadas à descendência consangüínea foi perdendo relevância no sistema representativo. Como o antigo nepotismo se caracteriza (ou se caracterizava, no caso dos EUA) por atribuir direitos independentes do mérito e apenas por motivos de parentesco, o 
resultado foi a ampliação do estigma do nepotismo à medida que os valores meritocráticos se alastravam pelas sociedades.

Em um grau de abstração maior, Bellow nos mostra que há diferenças do nepotismo praticado nas tribos africanas, castas indianas e clãs chineses e aquele característico da era cristã no Ocidente. "Em todas as sociedades nepotistas, antigas ou clássicas, o indivíduo como tal não existe separado da família e do grupo de parentesco. [...] O nepotismo ocidental, apesar de emergir do mesmo complexo institucional, valores e práticas, foi muito mais individualista que seus precursores antigos e clássicos" (p. 158). No Ocidente, houve um declínio gradual do grupo de parentesco e o fortalecimento correspondente da autonomia individual, resultado do desenvolvimento do Estado, da Igreja e do mercado, que foram decisivos no enfraquecimento dos grupos tribais e dos vínculos primordiais.

O capítulo VI, por exemplo, descreve a "era de ouro do nepotismo", período entre os séculos XVI e XVII da Europa, onde as relações sociais feudais já estavam em acentuado declínio e o desenvolvimento da burocracia dos Estados modernos - que também estão se formando - ainda não havia se consolidado. Neste terreno, a ambição dinástica prosperou e, com ela, o nepotismo irrestrito. Exatamente nesse período, o nepotismo começou a ganhar as conotações negativas que se associam à prática, pois a distinção entre esfera pública e privada foi ganhando corpo. A história européia, doravante, passa a ser o conflito permanente entre as forças da solidariedade nepotista e sua tríade rival: o individualismo, a eficiência de mercado e a ideologia meritocrática.

Ao analisar o desenvolvimento do nepotismo nos Estados Unidos, alguns notáveis da história desse país têm sua trajetória pública examinada de um novo ângulo: o uso das relações familiares como instrumento de promoção das carreiras públicas. Benjamin Franklin, George Washington, John Adams, Thomas Jefferson - para quem a "dádiva do cargo [de presidente]" era um "terrível fardo" que oprime qualquer chefe do Executivo -, Andrew Jackson - pai 
fundador do "spoils system" -, Lincoln, os Roosevelt, os Kennedy, entre outros.

Bellow retoma, no final do livro, a discussão sobre a natureza do novo nepotismo ressaltando que ele tem duas diferenças em relação às formas clássicas. No novo nepotismo, as carreiras dos filhos são definidas por estes, não por seus pais, o que aumentou o grau de liberdade dos descendentes. Mas o traço mais marcante - e distintivo - das novas formas de nepotismo é combinar os critérios de nascimento com os critérios de mérito, de modo que a trajetória da carreira dos descendentes se torne muito mais compatível com os modernos critérios democráticos. "O novo nepotismo difere ao combinar os privilégios do nascimento com a lei de ferro do mérito, de modo muito menos ofensivo à sensibilidade democrática" ( $p$. 15).

O novo nepotismo do sistema social norte-americano concilia um impulso biológico - promover os seus descendentes - e um valor moral que lhe é antagônico: o sistema de mérito. $\mathrm{O}$ resultado, o nepotismo meritocrático, continua a manter fração expressiva das posições-chave do sistema social ocupada por herdeiros biológicos; porém esses herdeiros carregam não apenas os genes, mas as qualificações indispensáveis à posição que ocupam: "Cada sociedade [...] desenvolve uma fórmula adequada para suas necessidades e condições. A América desenvolveu uma que representa a acomodação histórica entre nossa necessidade de continuidade social e biológica e nosso ideal liberal". É isso que singulariza o contemporâneo nepotismo norte-americano em relação ao nepotismo das oligarquias gregas e romanas, das castas indianas ou das tribos africanas.

Ao fim do livro de Bellow, o que se vê é uma longa e detalhada história sobre a prática de favorecimento de parentes na esfera política e dos negócios, levada à frente por políticos e empreendedores capitalistas.

Mas sua análise é confusa quanto ao conceito de nepotismo. O nepotismo, para Bellow, não se restringe apenas à esfera pública 
ou à administração pública. Além disso, a certa altura há referências ao "nepotismo étnico", para descrever formas de favorecimento que não necessariamente se associam ao parentesco, mas a outros tipos de vínculos de lealdade. Lá pelo final do livro, por exemplo, propõe a refundação dos "pais mitológicos" da sociedade norte-americana, como forma de alterar a percepção social dos cidadãos, e, dessa forma, fazer com que eles se percebam como membros de uma mesma "família nacional": "Assim como Clovis fundou a nação francesa afirmando que francos e gauleses eram ambos descendentes de heróis troianos, os futuros cidadãos da multirracial América desejam pensar a si mesmos como "filhos" de Thomas Jefferson e Sally Hemings" (p. 484). De tão maleável, é difícil pensar em termos comparativos e analiticamente úteis o uso do termo nepotismo. Além disso, se, como a passagem mostra, o nepotismo é, em última instância, subordinado aos sabores das representações sociais, como subordiná-lo ao imperativo biológico, que Bellow tanto enfatiza?

Voltando os olhos para o Brasil, In praise of nepotism nos faz pensar sobre a importância do nepotismo na administração pública brasileira e quais as cosmovisões dos cidadãos, administradores e políticos sobre a questão. Neste momento, vemos o confronto entre a visão liberal-progressista, que associa o nepotismo ao atraso de uma administração com fortíssimos traços patrimoniais-burocráticos, e a visão alternativa, que parte expressiva dos políticos partilha - e que não fogem muito dos argumentos do nepotismo meritocrático - segundo a qual não há problema em ter parentes empregados se eles estão trabalhando como qualquer outro funcionário. Neste caso, dizem, entre um parente-técnico e um técnico não-parente, a primeira escolha é sempre mais lógica e racional, especialmente em um sistema político como o nosso que estende os braços por todos os escalões da administração pública com as incontáveis "nomeações de confiança". No que tange à nomeação de assessores diretos, a lógica da nomeação dos parentes soa ainda mais implacável; afinal, argumentam os políticos, como indicar alguém que não seja da extrema confiança, em um terreno marcado por rasteiras e traições como é a política faccional brasileira? A variável fundamental para 
justificar a contratação é a confiança no nomeado, que, via de regra, é máxima, quando se trata de um parente próximo.

Outro aspecto que também parece encontrar ressonância na sociedade brasileira - a outra face da lógica que acabei de mencionar - é que nós não nos opomos tanto ao nepotismo ou ao nepotista, mas sim àquele que foi indicado, quando não apresenta competências específicas. "O nepotismo parece ser um problema apenas quando o beneficiário é manifestamente desqualificado" (p. 11), diz Bellow sobre a percepção social dos norte-americanos.

O ponto é que vivemos um momento de mudanças cruciais no debate público no que se refere à prática do nepotismo. Os ataques a esta são crescentes e uma onda moral em favor de sua proibição ganha fôlego na sociedade civil. Mas será que o fôlego será longo o suficiente para produzir mudanças importantes na administração pública brasileira? A crer na posição e no desejo de Bellow, isso é improvável já que, "no fim da história, não há dúvida: o nepotismo deve e continuará" (p. 78). Não teria Bellow que dar uma olhada nos sistemas administrativos mais burocratizados do mundo para temperar sua convicção?

\section{Nota}

1 A bióloga Mary Maxwell diz que "o nepotismo é a norma para as espécies sociais. [...] a prática do nepotismo define as espécies sociais" (grifos no original). 